\title{
Rough and Tumble Play and Gender in Kindergarten: Perceptions of Kindergarten Teachers
}

\author{
Gerasimos S Koustourakis (Corresponding author) \\ University of Patras, Greece
}

Christina Rompola

Aginoros 18, 263.33 Ities Patras, Greece

\author{
Anna Asimaki \\ University of Patras, Greece
}

Received: May 8, 2015 Accepted: June 12, 2015 Published: June 22, 2015

doi:10.5296/ire.v3i2.7570 URL: http://dx.doi.org/10.5296/ire.v3i2.7570

\begin{abstract}
The first purpose of this research, which was carried out using questionnaire and semi-structures interview, was to examine the types of Rough and Tumble Play (RTP) that are played in the Greek kindergarten school. The second aim of this study was to identify the kindergarten teachers' perceptions on RTP as well as their reactions in the cases that pupils are engaged in RTP in their schools. The types of RTP that pinpointed in the Greek kindergarten schools were verbal teasing, punching and hitting with or without physical contact, fighting/wrestling, pile on, chasing, spinning, tickling, rolling around, open hand slapping and protect - rescue games. The findings of the research, in which 67 female kindergarten teachers took part, suggested that the forms of RTP that include competition and intense physical contact are played almost exclusively by boys. More specifically these types of RTP are fighting/wrestling, punching and hitting, open hand slapping and pile on, which, according to the kindergarten teachers, correspond to boys and they put them in the list of the forbidden plays, as reported by the school rules they establish in their schools. Thus, when the kindergarten teachers realize that their students play some of the specific RTP intervene in order to stop it, so that there is not a possibility of injury.
\end{abstract}

Keywords: Rough and Tumble Play, Gender, Kindergarten, Kindergarten teachers 


\section{Introduction}

Play is an important element in the children's socializing procedure (Giddens, Duneier, Appelbaum, \& Carr, 2000; Handel, Cahil, \& Elkin, 2007; Hughes, Kroehler, \& Vander Zanden, 2005; Wyness, 2012). It is, thus, integrated in the official curriculum of the kindergarten school, because through activities that use play, one can achieve the development of the students' kinesthetic, linguistic and socio-emotional skills and abilities (Frost, Wortham, \& Reifel, 2008; Wood \& Attfield, 2005; Wyness, 2012).

Rough and Tumble Play (RTP) is a special type of physical play, that is implemented during students' interaction, mainly in the kindergarten and primary school. RTP is defined as a vivid and action physical play that can include verbal teasing, physical contact with light strikes, punching and hitting with or without physical contact that they do not aim at causing pain to the partner, open-hand slapping (as slapping the air with open hands or by slightly touching the other child's face), poke and grappling between children not using much force and laughing at the same time, play fighting-wrestling until the partner falls on the ground, chasing, rolling around, spinning - either around themselves or around an object, tickling, pile on that children lying one upon the other forming a pile, and protect - rescue games (Brett, Valle-Riestra, Fischer, Rothlein, \& Hughes, 2002; Jarvis, 2006; Logue \& Harvey, 2010; Pelligrini, 1989; Smith, 1997; Tannock, 2008). Consequently, RTP is a physical play that includes action and strength expressions. When children play RTP wear a "play face" (Storli, 2013), like teeth showing, growling and extravagant grimaces (Freeman \& Brown, 2004; Pellegrini, 1989; Smith \& Pellegrini, 2013; Reed, Brown, \& Roth, 2000). Play face helps in creating a framework where certain behaviors that otherwise would be characterized as violent, are converted into a game. RTP rules include self-handicapping and mutuality, where roles can be exchanged, as the defender can be the aggressor the next moment. Besides, friends usually join RTP and no one aims at hurting the other (Carlson, 2011; Freeman \& Brown, 2004; Pellegrini \& Smith, 1998; Schåfer \& Smith, 1996; Scott \& Panksepp, 2003).

Approaching cases that refer to RTP is an issue, to some extent, in the international scientific literature (Pellegrini \& Smith, 1998; Smith \& Pellegrini, 2013; Tannock, 2008). Research on RTP mainly focuses on early childhood and early school age and, mostly, approaches the countries of USA and Canada. In these studies, the participation of gender in RTP is examined (see: Boulton, 1996; Jarvis, 2004; Reed \& Brown, 2000; Storli, 2013), or there is an approach concerning the teachers' or parents' perceptions on RTP (see: Coplan, Bullock, Archbell, \& Bosacki, 2015; Di Carlo, Baumgartner, Ota, \& Jenkins, 2015; Fletcher, May, St George, Morgan, \& Lubans, 2011; Tannock, 2008). There is also observation research on RTP developing among father and son and, consequently, apprehension of the impact on the boys' behavior forming and plays at school (see: Flanders, Leo, Paquette, Pihl, \& Séguin, 2009; McBride-Chang \& Nagy Jacklin, 1993). The research to be presented is the first carried out in Greece and there is an attempt to contribute to academic literature, offering a picture of how gender affects RTP choice in kindergarten.

According to Mead (1982) the play in which the child takes part during early childhood is a really crucial factor in developing his/her self. What's more, play is the most important 
children's action that contributes to "role-taking" and especially the "role-taking" of other's. Through play, pupils interact with their classmates and pick up a lot of different roles that help in their linguistic and social skills development. RTP involves action and exchanging roles, thus helping infants' physical abilities development and their gradual emotional maturing. This is true because through RTP they express their feelings and they get help in order to understand others' feelings. The forms of RTP that students choose to play are influenced by the dispositions they carry at school. Those dispositions, according to Bourdieu (2000), are significant element of the primary habitus that children acquire through their socialization in their family. More specifically, Bourdieu (2006, p. 88) defines habitus as a "system of continuous and transferable dispositions" that form and lead - as an internal compass - the way each person thinks, acts, talks and feels (Asimaki \& Koustourakis, 2014, p. 125). Habitus is a product of a social engraving procedure, it is achieved through practices, and it is oriented towards practical choices and behaviors. This is the reason why individuals' dispositions direct them into differentiated practice choices, depending on their social origin and gender (Bourdieu, 2002). What's more, it is upon the primary and starting habitus each individual acquires inside his/her family that the secondary habitus is "transplanted", under the impact of the school, and the tertiary habitus which is obtained during a professional practice (Bourdieu, 2003).

In the RTP case, the first forms of play are noticed in infancy, during the interaction between child and their parents and especially between father and son. In this way, the child's later preferences and play choices are gradually formed and are seen in the kindergarten (Carlson, 2011; Flanders et al., 2009; Stevenson, 2014). Thus, under the impact of the "gender habitus", boys prefer RTP to a greater extent than the girls and, indeed, they choose competitive power plays, whereas girls choose lighter forms of RTP (Pellegrini \& Smith, 1998; Storli, 2013). Since the primary habitus is under a procedure of constant restructuring (Swartz, 1997), the pupils' dispositions to join RTP are reformed through the kindergarten teachers' intervention. In this case, the kindergarten teachers' gender-based habitus is activated and it is the latter that led them to choose the specific profession, since in Greece, as well as in other countries, early childhood is dominated by women teachers (Cooney \& Bittner, 2001; Sumsion, 2000). Specifically, pre-school age is considered to be closer to female nature and to the traditional definition of female activities (Bourdieu, 2003). On the contrary, RTP seems to be a male action area. This seems to be true as research outcomes show that most of the children joining RTP are boys (Jarvis, 2004; Pellegrini \& Smith, 1998; Reed et al., 2000; Tannock, 2005, 2008). However, female kindergarten teachers, influenced by their own gender habitus, define the forms and the type of the games that their students are allowed to play. Thus, the RTP forms that seem to include competition and fighting spirit, especially when played by boys, are often supressed by the kindergarten teachers, with the excuse that violence is fostered (Coplan et al., 2015; DiCarlo et al., 2015; Freeman \& Brown, 2004; Reed et al., 2000).

The aim of this research is the apprehension of RTP forms in the Greek kindergarten, depending on the students' gender, as well as exploring the teachers' perception about the particular games, which their students are allowed to play. 
The research questions that will concern us are:

- Which RTP forms the kindergarten teachers observed during the interaction between pre-schoolers in their schools and what is the role of the gender in it.

- Which are the kindergarten teachers' perceptions about RTP, depending on the students' gender and how the former react when they realize the specific game forms are played during the interaction of pre-schoolers in their school.

\section{Methodology}

\subsection{Participants}

The research sample includes 67 female kindergarten teachers teaching in schools around the region of Patras. Their average age was 43.7 years (Standard Deviation/SD 6.8 years, minimum age being 25 years and maximum age being 54 years). Concerning the sample members' teaching experience, the average professional service was 16.6 years (SD 7.6 years, maximum service time being 31 years and minimum service time being 1 year). Also, 58 kindergarten teachers $(86.6 \%)$ had four-year University degrees in educational sciences and early childhood education and 9 (13.4\%) had two-year kindergarten school of education degrees.

\subsection{Study Tools}

In order for the research to be carried out, a well-formed anonymous questionnaire was used. For the selection of the RTP occasions that are covered in the questionnaire, there was a former non-participant observation (Robson, 2007), where researchers observed pre-schoolers' RTP in the recess, during the Department of the Educational Sciences and Early Childhood Education of the University of Patras students' practical training. The questionnaire consists of two parts: a) questions that refer to demographic data (gender, age, teaching experience, studies); and, b) exploring research issues through closed questions, mainly answered using the four-degree Likert scale (not at all, a little, a lot, very much), which allows the statistic processing of the research data (Cohen, Manion, \& Morrison, 2007). In the questionnaire, there were also two open questions referring to: a) the rules of play teachers establish in their schools; and b) teachers' reactions when they realize their students use RTP, which may break the school rules.

Along with the questionnaire, semi-structured interview was used. The latter provided the opportunity to the teachers to thoroughly and deeply express their opinions about RTP and the way they handle its implementation in their schools (Mason, 2002).

\subsection{Procedure}

Before using the questionnaire, we gave it as a pilot project to 4 kindergarten teachers, who were excluded from the research in order to complete it and propose corrective adjustments (Cohen et al., 2007). Thus, following the teachers' recommendations, two more fields were added to the question that referred to the factors that influence the RTP choice by the pre-schoolers. 
The research was carried out during spring 2014, handing out the questionnaire to the teachers of the accessible kindergarten schools; convenience sampling was used (Cohen et al., 2007, pp. 113-114). Thus, the findings represent the prevailing trend in Greek Kindergarten schools and they should not be generalized. 108 questionnaires were distributed, out of which 67 were given back fully completed $(62.03 \%)$; there was a statistic processing upon their data through SPSS. The analysis of reliability showed that the reliability coefficient Cronbach's Alpha was 0.81. This result shows that the data collection procedure was too reliable and complied with to the targets research conduct.

The questionnaires collection was followed by a semi-structured interview, with the participation of 5 of the kindergarten teachers that completed the questionnaire and accepted our request. The interviews were tape recorded with the teachers' consent (Robson, 2007). Afterwards, there was a transcription of the interviews material and qualitative content analysis was applied to the written text, considering the topic as the unit of analysis. More specifically, the topic includes this part of the text that may consist of one or more sentences, from which a whole meaning comes out for each specific question posed on the respondents (Mason, 2002; Robson, 2007). In each question, the resulting topics were grouped together depending on their content similarity. Finally, it should be noted that the same approach was used for the answers content qualitative analysis of the two open questions of the questionnaire.

\section{Findings}

Table 1 presents the findings of the questionnaire data processing that refer to the forms of RTP that the teachers mentioned their students used in their schools.

Table 1. Rough and Tumble Play in the kindergarten school

\begin{tabular}{lccccc}
\hline & Not at all & A little & A lot & Very much & Mean (SD) \\
\hline Verbal teasing & 0 & 43 & 22 & 2 & 2.39 \\
& $(0.0 \%)$ & $(64.2 \%)$ & $(32.8 \%)$ & $(3.0 \%)$ & $(0.5)$ \\
Punching and hitting with or & 5 & 35 & 25 & 2 & 2.36 \\
without physical contact & $(7.5 \%)$ & $(52.2 \%)$ & $(37.3 \%)$ & $(3.0 \%)$ & $(0.67)$ \\
Poke and grappling & 1 & 18 & 40 & 8 & 2.82 \\
& $(1.5 \%)$ & $(26.9 \%)$ & $(59.7 \%)$ & $(11.9 \%)$ & $(0.65)$ \\
Play fighting / wrestling & 30 & 30 & 5 & 2 & 1.69 \\
& $(44.8 \%)$ & $(44.8 \%)$ & $(7.5 \%)$ & $(3.0 \%)$ & $(0.74)$ \\
Pile on & 23 & 31 & 10 & 3 & 1.90 \\
& $(34.3 \%)$ & $(46.3 \%)$ & $(16.9 \%)$ & $(4.5 \%)$ & $(0.82)$ \\
Chasing & 1 & 10 & 26 & 30 & 3.27 \\
& $(1.5 \%)$ & $(14.9 \%)$ & $(38.8 \%)$ & $(48.8 \%)$ & $(0.77)$ \\
Spinning & 10 & 29 & 21 & 7 & 2.37 \\
& $(14.9 \%)$ & $(43.3 \%)$ & $(31.3 \%)$ & $(10.4 \%)$ & $(0.87)$ \\
Tickling & 26 & 35 & 6 & 0 & 1.70 \\
& $(38.8 \%)$ & $(52.2 \%)$ & $(9.0 \%)$ & $(0.0 \%)$ & $(0.63)$ \\
Rolling around & 32 & 26 & 9 & 0 & 1.65 \\
& $(47.8 \%)$ & $(38.8 \%)$ & $(13.4 \%)$ & $(0.0 \%)$ & $(0.70)$ \\
Open hand slapping & 45 & 15 & 7 & 0 & 1.43 \\
& $(67.2 \%)$ & $(22.4 \%)$ & $(10.4 \%)$ & $(0.0 \%)$ & $(0.68)$ \\
Protect - rescue games & 3 & 19 & 34 & 11 & 2.79 \\
& $(4.5 \%)$ & $(28.4 \%)$ & $(50.7 \%)$ & $(16.4 \%)$ & $(0.76)$ \\
\hline
\end{tabular}


Studying Table 1 data, it is shown that in the sample teachers' schools, RTP forms that were extensively used by pre-schoolers were (cases "a lot" and "very much"): chasing (87.6\%, $\mathrm{M}=3.27, \mathrm{SD}=0.77)$, poke and grappling $(71.6 \%, \mathrm{Mean} / \mathrm{M}=2.82, \mathrm{SD}=0.65)$ and protect rescue games $(67.1 \%, \mathrm{M}=2.79, \mathrm{SD}=0.76)$. Also, there was extended use of: spinning (cases 'a lot' and 'very much': $41.7 \%, \mathrm{M}=2.37, \mathrm{SD}=0.87)$, punching and hitting $(40.3 \%, \mathrm{M}=2.36$, $\mathrm{SD}=0.67)$ and verbal teasing $(35.8 \%, \mathrm{M}=2.39, \mathrm{SD}=0.5)$. Moreover, RTP forms that were less mentioned were: tickling (case 'a little': $52.2 \%, \mathrm{M}=1.70, \mathrm{SD}=0.63)$, pile on $(46.3 \%, \mathrm{M}=1.90$, $\mathrm{SD}=0,82)$, fighting/wrestling (44.8\%, $\mathrm{M}=1.69, \mathrm{SD}=0.74)$, rolling around (38.8\%, $\mathrm{M}=1.65$, $\mathrm{SD}=0.70)$ and open hand slapping $(22.4 \%, \mathrm{M}=1.43, \mathrm{SD}=0.68)$.

The percentage of pupils' participation in RTP by gender, who attended in the schools of the kindergarten teachers of the sample, is presented in the Table 2.

Table 2. Percentage of RTP by gender in the kindergarten school

\begin{tabular}{|c|c|c|c|c|c|}
\hline & & Not at all & A little & A lot & Very much \\
\hline \multirow[t]{2}{*}{ Verbal teasing } & Boys & 4.5 & 67.2 & 25.4 & 3.0 \\
\hline & Girls & 9.0 & 53.7 & 31.3 & 4.5 \\
\hline \multirow{2}{*}{$\begin{array}{l}\text { Punching and hitting with or } \\
\text { without physical contact }\end{array}$} & Boys & 1.5 & 40.3 & 43.3 & 14.9 \\
\hline & Girls & 71.8 & 25.4 & 3.0 & \\
\hline \multirow[t]{2}{*}{ Poke and grappling } & Boys & 9.0 & 37.3 & 37.3 & 16.4 \\
\hline & Girls & 16.4 & 56.7 & 25.4 & 1.5 \\
\hline \multirow[t]{2}{*}{ Play fighting / wrestling } & Boys & 47.8 & 11.9 & 32.8 & 7.5 \\
\hline & Girls & 86.6 & 13.4 & & \\
\hline \multirow[t]{2}{*}{ Pile on } & Boys & 38.7 & 28.4 & 28.4 & 4.5 \\
\hline & Girls & 61.2 & 32.8 & 4.5 & 1.5 \\
\hline \multirow[t]{2}{*}{ Chasing } & Boys & 1.5 & 13.4 & 38.8 & 46.3 \\
\hline & Girls & 1.5 & 25.4 & 41.8 & 31.3 \\
\hline \multirow[t]{2}{*}{ Spinning } & Boys & 17.9 & 62.7 & 13.4 & 6.0 \\
\hline & Girls & 19.4 & 43.3 & 29.8 & 7.5 \\
\hline \multirow[t]{2}{*}{ Tickling } & Boys & 52.2 & 43.3 & 3.0 & 1.5 \\
\hline & Girls & 44.8 & 47.8 & 6.0 & 1.5 \\
\hline \multirow[t]{2}{*}{ Rolling around } & Boys & 50.7 & 35.8 & 10.4 & 3.0 \\
\hline & Girls & 64.2 & 32.8 & 1.5 & 1.5 \\
\hline \multirow[t]{2}{*}{ Open hand slapping } & Boys & 49.3 & 34.3 & 13.4 & 3.0 \\
\hline & Girls & 71.6 & 26.9 & 1.5 & \\
\hline \multirow[t]{2}{*}{ Protect - rescue games } & Boys & 6.0 & 53.7 & 35.8 & 4.5 \\
\hline & Girls & 10.4 & 38.8 & 39.8 & 12.0 \\
\hline
\end{tabular}

Studying Table 2 data, it is shown that girls mainly (cases 'a lot' and 'very much') joined: chasing (71.3\%, $\mathrm{M}=3.16, \mathrm{SD}=0.86)$, protect-rescue games $(49.2 \%, \mathrm{M}=2.50, \mathrm{SD}=0.84)$ and spinning $(35.9 \%, \mathrm{M}=2.24, \mathrm{SD}=0.86)$. On the contrary, it seemed they avoided and did not 
join (case "not at all") games that involved close physical contact and power exercising like: play fighting/wrestling $(85.1 \%, \mathrm{M}=1.13, \mathrm{SD}=0.34)$, punching and hitting with or without physical contact $(71.6 \%, \mathrm{M}=1.31, \mathrm{SD}=0.52)$, open hand slapping $(71.6 \%, \mathrm{M}=1.29, \mathrm{SD}=0.49)$, rolling around $(64.2 \%, \mathrm{M}=1.37, \mathrm{SD}=0.57)$ and pile on $(61.2 \%, \mathrm{M}=1.43, \mathrm{SD}=0.63)$. Both the boys' and girls' first preference (cases "a lot" and "very much") was chasing ( $85.1 \%, \mathrm{M}=3.29$, $\mathrm{SD}=0.75)$. However, as the research proceeds, their preferences differentiate, as boys focus on (cases "a lot" and "very much") games of strength and intense action as: punching and hitting (58.2\%, $\mathrm{M}=2.71, \mathrm{SD}=0.73)$ and fighting/wrestling $(52.2 \%, \mathrm{M}=2.59, \mathrm{SD}=0.85)$.

Table 3 presents a picture of boys' and girls' participation in different RTP forms in the schools of the research. That is, it is studied whether boys and girls joined RTP together, or only children of the same gender joined the game.

Table 3. Participation of male and female students in the RTP

\begin{tabular}{lccc}
\hline & $\begin{array}{c}\text { RTP was played } \\
\text { only by the Boys }\end{array}$ & $\begin{array}{c}\text { RTP was played } \\
\text { only by the Girls }\end{array}$ & $\begin{array}{c}\text { Boys and girls } \\
\text { played together }\end{array}$ \\
\hline $\begin{array}{l}\text { Verbal teasing } \\
\text { Punching and hitting with or without }\end{array}$ & $16(23.9 \%)$ & $10(14.9 \%)$ & $41(61.2 \%)$ \\
physical contact & $58(86.6 \%)$ & & $9(13.4 \%)$ \\
Poke and grappling & $13(19.4 \%)$ & $7(10.4 \%)$ & $47(70.1 \%)$ \\
Play fighting / wrestling & $65(97.0 \%)$ & & $2(3.0 \%)$ \\
Pile on & $41(61.2 \%)$ & & $26(38.8 \%)$ \\
Chasing & $1(1.5 \%)$ & $1 .(1.5 \%)$ & $65(97.0 \%)$ \\
Spinning & $1(1.5 \%)$ & $9(13.4 \%)$ & $57(85.1 \%)$ \\
Tickling & $3(4.5 \%)$ & $36(53.7 \%)$ & $28(41.8 \%)$ \\
Rolling around & $30(44.8 \%)$ & $2(3.0 \%)$ & $35(52.2 \%)$ \\
Open hand slapping & $49(73.1 \%)$ & $5(7.5 \%)$ & $13(19.4 \%)$ \\
Protect - rescue games & $9(13.4 \%)$ & $5(7.5 \%)$ & $53(79.1 \%)$ \\
\hline
\end{tabular}

Studying Table 3 data, it is shown that in the sample teachers' kindergarten schools, girls mainly play tickling (53.7\%) on their own. Also, in most RTP cases, pre-schoolers of both genders participate and this finding mainly focus on the following: chasing $(97.0 \%)$, spinning $(85.1 \%)$, protect - rescue games $(79.1 \%)$, poke and grappling $(70.1 \%)$, verbal teasing $(61.2 \%)$ and rolling around (52.2\%). Plays that include power, confrontation or/and conflict are presented as exclusively boyish ones. These refer to RTP forms like fighting - wrestling (97.0\%), punching and hitting with or without physical contact $(86.6 \%)$, open hand slapping $(73.1 \%)$ and pile on $(61.3 \%)$.

Findings resulting from Table 3 data analysis show a close relevance to Table 4 findings, in which one can note kindergarten teachers' opinion about RTP forms they consider that suit their students depending on their gender. 
Table 4. Kindergarten teachers' opinion on RTP forms that suit according to the children's gender

\begin{tabular}{lccc}
\hline & Boys & Girls & Both sexes \\
\hline Verbal teasing & $13(19.4 \%)$ & $10(14.9 \%)$ & $44(65.7 \%)$ \\
$\begin{array}{l}\text { Punching and hitting with or without } \\
\text { physical contact }\end{array}$ & $58(86.6 \%)$ & & $9(13.4 \%)$ \\
Poke and grappling & $12(17.9 \%)$ & $7(10.4 \%)$ & $48(71.6 \%)$ \\
Play fighting / wrestling & $62(92.5 \%)$ & & $5(7.5 \%)$ \\
Pile on & $36(53.7 \%)$ & & $31(46.3 .8 \%)$ \\
Chasing & & & $67(100 \%)$ \\
Spinning & $2(3.0 \%)$ & $7(10.4 \%)$ & $58(86.6 \%)$ \\
Tickling & $3(4.5 \%)$ & $22(32.8 \%)$ & $42(62.7 \%)$ \\
Rolling around & $20(29.8 \%)$ & $2(3.0 \%)$ & $45(67.2 \%)$ \\
Open hand slapping & $39(58.2 \%)$ & $5(7.5 \%)$ & $23(34.3 \%)$ \\
Protect - rescue games & $5(7.5 \%)$ & $2(3.0 \%)$ & $60(89.6 \%)$ \\
\hline
\end{tabular}

Studying Table 4 data shows that RTP games are divided into two categories: mixed forms, where both boys and girls participate and exclusively boyish games. Thus, according to sample teachers' opinions, it seems that games like fighting - wrestling (92.5\%), punching and hitting $(86.6 \%)$, open hand slapping $(58.2 \%)$ and pile on $(53.7 \%)$ almost exclusively appeal to boys. As far as girls are concerned, teachers consider tickling (32.8\%) suits them a lot, whereas, as for the rest RTP forms, they can be played by both boys and girls together. More specifically, these mixed forms are: chasing (100\%), protect - rescue games $(89.6 \%)$, spinning $(86.6 \%)$, poke and grappling $(71.6 \%)$, rolling around $(67.2 \%)$ and tickling $(62.7 \%)$.

The interview findings show that kindergarten teachers are influenced by the children's gender in order to show tolerance when, for example, note that some girls are involved in RTP forms which are considered to be boyish; and this is because the teachers consider girls to have a milder character:

"I know that girls won't get hurt, they will play the game without getting hurt. But if they are boys, as some naughty kids are, I will show no tolerance, because I know they will misbehave a little. This applies to all games" (Interview 2 - I.2)

In this particular occasion it is obvious that the teacher's dispositions, which are "gender-based unconscious schemata" and are built through her own historic route, work as building structures and are reproduced in their pre-schoolers' approach (Bourdieu, 2002, p. 188).

Table 5 presents the perceptions of the kindergarten teachers about the factors that influence pre-schoolers' choices to play RTP. 
Table 5. Factors influencing pupils' RTP choices

\begin{tabular}{lccccc}
\hline & Not at all & A little & A lot & Very much & Mean (SD) \\
\hline Family environment effect & 0 & 1 & 29 & 37 & 3.54 \\
& $(0.0 \%)$ & $(1.5 \%)$ & $(43.3 \%)$ & $(55.2 \%)$ & $(0.53)$ \\
Pupils' linguistic communication & 0 & 8 & 39 & 20 & 3.18 \\
ability & $(0.0 \%)$ & $(12.0 \%)$ & $(58.1 \%)$ & $(29.9 \%)$ & $(0.63)$ \\
Gender & 0 & 11 & 42 & 14 & 3.04 \\
& $(0.0 \%)$ & $(16.4 \%)$ & $(62.7 \%)$ & $(20.9 \%)$ & $(0.59)$ \\
Computer games & 0 & 2 & 31 & 33 & 3.48 \\
& $(0.0 \%)$ & $(3.0 \%)$ & $(47.7 \%)$ & $(49.3 \%)$ & $(0.56)$ \\
Watching TV programs & 0 & 4 & 22 & 41 & 3.55 \\
& $(0.0 \%)$ & $(6.0 \%)$ & $(32.8 \%)$ & $(61.2 \%)$ & $(0.61)$ \\
Pupils' social environment & 2 & 16 & 37 & 12 & 2.88 \\
& $(3.0 \%)$ & $(23.9 \%)$ & $(55.2 \%)$ & $(17.9 \%)$ & $(0.73)$ \\
Imitating other children & 0 & 14 & 35 & 18 & 3.06 \\
& $(0.0 \%)$ & $(20.9 \%)$ & $(52.2 \%)$ & $(26.9 \%)$ & $(0.69)$ \\
Size of school yard & 10 & 39 & 17 & 1 & 2.13 \\
& $(14.9 \%)$ & $(58.2 \%)$ & $(25.4 \%)$ & $(1.5 \%)$ & $(0.67)$ \\
Quality of school yard (e.g. grass, & 12 & 36 & 15 & 4 & 2.16 \\
gravel, asphalt) & $(17.9 \%)$ & $(53.7 \%)$ & $(22.4 \%)$ & $(6.0 \%)$ & $(0.79)$ \\
\hline
\end{tabular}

Studying Table 5 data shows that kindergarten teachers consider the following to be important affecting factors (cases "a lot" and "very much") as far as students' RTP choices are concerned: children's socialization inside the family $(98.2 \%, \mathrm{M}=3.54, \mathrm{SD}=0.53)$, computer and internet games that include violence $97 \%, \mathrm{M}=3.48, \mathrm{SD}=0.56$ ), kids' TV programs including cartoons with competition and battle scenes $(94 \%, \mathrm{M}=3.55, \mathrm{SD}=0.61)$, pre-schooler's communicative ability $(88 \%, \mathrm{M}=3.18, \mathrm{SD}=0.63)$ and gender $(83.6 \%, \mathrm{M}=3.04$, $\mathrm{SD}=0.59$ ). Also, other important factors (cases 'a lot' and 'very much') that lead pre-schoolers to RTP actions are considered: imitation of schoolmates' behavior $(79.1 \%, \mathrm{M}=3.06, \mathrm{SD}=0.69)$ and the effect of the social environment of the area they live $(73.1 \%, \mathrm{M}=2.88, \mathrm{SD}=0.73)$. On the contrary, the size of the school yard and the material it is made of play a rather small role in RTP demonstration.

Qualitative analysis of the interview content showed that children are pushed towards choosing a particular RTP form, according to the socializing factors effect:

\section{“Of course, home and TV affects verbal teasing” (I.3).}

In this occasion, it seems that the family works as a habitus formation "principal", also through the language communicational symbolic system. What's more, Media and especially television as a social practice and a means of "verbal" propaganda, transmits to children the gender-based stereotypes and traditional schemata on boys' and girls' roles (Bourdieu, 1999, p. 241; Bourdieu, 2000, p. 127). 
Also, interaction with classmates and imitating their behavior plays an important role in encouraging pre-schoolers to participate in RTP:

"Imitation works in piling. When one starts to fall, the others go on falling one on the other" (I.1).

The particular teacher's story presents the "attitude-taking" of others by the children. According to Mead this attitude along with "role-taking" of others is one of the most important socializing mechanisms (Mead, 1982; Mihalakopoulos, 1990, p. 122).

The results of the open question referring to the game rules that teachers impose on their students showed that the following were forbidden: a) physical contact between pupils, as well as conflict and confrontation games (52 cases, 77.6\%), b) behaviors that come to contrast with promoting co-operation and respect towards others, and c) verbal teasing, as well as insulting expressions ( 8 cases, 11.9\%). There are similar results coming from the interviews data analysis, as it is shown from the following indicative quotations:

"...to respect their classmates. To be careful when they run fast not to crush onto other students who usually run very fast. Not to beat and pull their classmates' clothes" (I.5)

"Mainly, not to hit each other, not to climb, not to get on the stairs, respect one another and not to use insulting verbal expressions" (I.4).

Table 6. School rules braking degree, depending on students' RTP forms

\begin{tabular}{lccccc}
\hline & Not at all & A little & A lot & Very much & Mean (SD) \\
\hline Verbal teasing & 18 & 28 & 12 & 9 & 2.29 \\
Punching and hitting with or & $(26.9 \%)$ & $(41.8 \%)$ & $(17.9 \%)$ & $(13.4 \%)$ & $(0.95)$ \\
without physical contact & 0 & 11 & 32 & 24 & 3.20 \\
Poke and grappling & $(0.0 \%)$ & $(16.4 \%)$ & $(47.8 \%)$ & $(35.8 \%)$ & $(0.71)$ \\
& 5 & 21 & 27 & 14 & 2.75 \\
Play fighting / wrestling & $(7.5 \%)$ & $(31.3 \%)$ & $(40.3 \%)$ & $(20.9 \%)$ & $(0.88)$ \\
& 2 & 4 & 23 & 38 & 3.49 \\
Pile on & $(3.0 \%)$ & $(6.0 \%)$ & $(34.3 \%)$ & $(56.7 \%)$ & $(0.75)$ \\
Chasing & 6 & 17 & 30 & 14 & 2.78 \\
Spinning & $(9.0 \%)$ & $(25.4 \%)$ & $(44.7 \%)$ & $(20.9 \%)$ & $(0.88)$ \\
& 34 & 24 & 7 & 2 & 1.66 \\
Tickling & $(50.7 \%)$ & $(35.9 \%)$ & $(10.4 \%)$ & $(3.0 \%)$ & $(0.72)$ \\
Rolling around & 37 & 23 & 5 & 2 & 1.59 \\
& $(55.2 \%)$ & $(34.3 \%)$ & $(7.5 \%)$ & $(3.0 \%)$ & $(0.76)$ \\
\hline
\end{tabular}


Table 6. School rules braking degree, depending on students' RTP forms (Continued)

\begin{tabular}{lccccc}
\hline & Not at all & A little & A lot & Very much & Mean (SD) \\
\hline Open hand slapping & 1 & 13 & 25 & 28 & 3.19 \\
& $(1.5 \%)$ & $(19.4 \%)$ & $(37.3 \%)$ & $(41.8 \%)$ & $(0.80)$ \\
Protect - rescue games & 16 & $31(46.3 \%)$ & $15(22.4 \%)$ & 5 & $2.13(0.87)$ \\
& $(23.8 \%)$ & & & $(7.5 \%)$ & \\
\hline
\end{tabular}

Analysing Table 6 data, it is shown that kindergarten teachers consider that pre-schoolers don't abide by the school rules while playing (cases 'a lot' and 'very much'): fighting wrestling (91\%, $\mathrm{M}=3.49, \mathrm{SD}=0.75)$, punching and hitting with or without physical contact (83.6\%, $\mathrm{M}=3.20, \mathrm{SD}=0.71)$, open hand slapping $(79.1 \%, \mathrm{M}=3.19, \mathrm{SD}=0.80)$, pile on $(65.6 \%$, $\mathrm{M}=2.78, \mathrm{SD}=0.88)$ and poke and grappling $(61.2 \%, \mathrm{M}=2.75, \mathrm{SD}=0.88)$. On the contrary, school rules are not broken (case "not at all") when children practise spinning $(55.2 \%$, $\mathrm{M}=1.59, \mathrm{SD}=0.76)$, tickling (53.7\%, $\mathrm{M}=1.52, \mathrm{SD}=0.61)$ and chasing $(50.7 \%, \mathrm{M}=1.66$, $\mathrm{SD}=0.72)$. Also, teachers show some tolerance to games such as rolling around $(\mathrm{M}=1.96$, $\mathrm{SD}=0.96)$, protect - rescue games $(\mathrm{M}=2.13, \mathrm{SD}=0.87)$ and verbal teasing $(\mathrm{M}=2.29, \mathrm{SD}=0.95)$. Moreover, one teacher participating in the interview notably added the following about RTP forms that include school rules breaking:

"Physical contact games, pushing, wrestling games and open hand slapping games" (I.3).

Finally, considering the sample teachers' answers about the way they react when they realize pre-schoolers practise RTP, it is shown that they intervene and stop the game when there is a danger of getting hurt (49 cases, $73.1 \%$ ), when they have already forbidden the game (10 cases, $14,9 \%$ ). when they realize that the students play with too much tension ( 9 cases, $13.4 \%$ ) and when it seems that the game will end up in confrontation and fighting between the students (9 cases, 13.4\%). Also, one kindergarten teacher (1.5\%) suggested that she doesn't allow RTP at all:

"I always intervene in order to avoid classroom disorder and maintain proper school function”.

Revealing examples of the teachers' immediate reactions in RTP cases that are evaluated by them as contrary to the school rules are the following interview extracts:

"I stop the game when it is dangerous for a kid to be hurt and when the game makes some kid feel inferior" (I.1)

"I intervene when there is a danger concerning their physical integrity. When someone pushes them to play and insists, despite their denial. When the school yard rules are broken” (I.3). 


\section{Discussion and Conclusions}

Kindergarten teachers' tertiary habitus that was formed as a result of their professional experience, seems to have an impact on the institutional habitus of their schools (Thomas, 2002), which, among others, consists of the students' acceptable behavior and play rules. These rules define what is acceptable, what is forbidden and what is tolerable. Thus, as far as RTP is concerned, forms like chasing, tickling and spinning are acceptable. On the contrary, according to the school rules, RTP forms that include physical contact are forbidden, in order not to promote violence and to ensure students' physical integrity. These forbidden RTP forms are fighting/wrestling, punching and hitting, open hand slapping, pile on, poke and grappling. This outcome is in accordance with other research corresponding outcomes (Coplan et al., 2015; DiCarlo et al., 2015; Tannock, 2008), in which it is shown that teachers find it difficult either to handle RTP, or to recognize the students' benefit when they practise RTP; and this happens because they support that RTP encourages violence.

Moreover, different RTP forms evaluation by women kindergarten teachers that participated in the research, seems to be influenced by their own gender-based dispositions. Thus, they support that RTP forms involving power, close physical contact and competition, such as fighting/wrestling, punching and hitting, open hand slapping and pile on almost exclusively appeal to boys. Also, the same teachers seem to be ready to show tolerance to hard RTP cases, when they are exercised by girls, because they consider their female character to be mild and rarely pushed towards extreme behavior.

Results concerning kindergarten teachers' opinions about RTP forms that can be exercised by both genders either autonomously, or co-operationally (see Table 4), are in accordance to real data that reveal boys' and girls' participation in different RTP forms at schools where the research was carried out (see Table 3). In this occasion, it seems that there is the realization of a self-fulfilling prophecy (Giddens et al., 2000; Hughes et al., 2005). However, this research was carried out towards the end of the school year and the institutional habitus of the kindergarten schools that was promoted by the teachers seems to have encouraged to a large extent pupils' RTP form. However, research data confirm that students practice RTP forms that are considered as unacceptable by teachers, such as fighting/wrestling. That is why they usually intervene to stop them. In this occasion, it seems that primary and gender-based habitus that pupils carry at school is activated. This is built within the framework of the family and functions as a "structuring structure" (Bourdieu, 2006, p.88), that affects students" action and leads their behavior, in an almost automatic way, to a particular playing practices choice. Besides, kindergarten teachers understand that pupils' habitus is manifested through dispositions that lead them to a satisfying or not communication with their classmates and to particular RTP forms choice that are immediately connected with gender. Thus, boys choose to play tough and powerful games with each other and to a greater extent than the girls, a fact that is in accordance with international research findings (Boulton, 1996; Cooney \& Bittner, 2001; Jarvis, 2004; Pellegrini, 1989; Reed \& Brown, 2000; Storli, 2013). Playing experiences with parents of the same gender seem that influence boys' preferences on RTP (Flanders et al., 2009; McBridge-Chang \& Nagy Jacklin, 1993). Also, certain family choices play an important role, as they greatly affect important, modern socialization factors, such as 
computer and/or internet games and watching TV cartoons that involve violence and aggressiveness (Hughes et al., 2005; Wyness, 2012). These particular factors create experiences, images and concepts for children and define their dispositions which direct them towards RTP choices that may often break the school rules and the acceptable way of playing in the kindergarten. Also, teachers support that imitation promotes pre-schoolers' participation in RTP forms such as pile on. What's more, pre-schoolers' personality formation is achieved through participation in games that allow role taking, where each child sees himself / herself through the other "important" children's eyes. Defining who these "important" others are to the child, depends on the importance of their role in his/her life, on the interaction frequency and on the emotional relationship between the two (Mead, 1982). In this occasion, the "important" others are the kindergarten teacher and the classmates.

Studying and analysing research data leads us to the following conclusions:

- RTP forms that were mainly noticed in the sample kindergarten schools were chasing, poke and grappling and protect - rescue games. Also, students participated to a large extent in spinning, verbal teasing, and punching and hitting, while they were less involved in tickling, pile on, fighting/wrestling, rolling around and open hand slapping. Popular RTP forms for both boys and girls were, spinning and protect - rescue games. However, students' RTP choices were defined by the rules teachers imposed depending on their tolerance and/or forbiddance on particular RTP forms.

- Gender-based habitus seems to have been activated in two occasions and defined the preferences, choices and practising of certain RTP forms in the research kindergarten schools. More specifically, it was activated in gender-based RTP choices. Here, it has been shown that only boys participated and tried to play games that include confrontation, intense motion and physical contact (fighting/wrestling, punching and hitting, open hand slapping and pile on). However, it seems that these specific games often break the institutional habitus of the schools. More specifically, here it seems that the students' habitus is proved more powerful than the school rules and restrictions as it works as a "conductorless orchestration" and defines in a spontaneous and unconscious way their actions and game choices (Bourdieu, 2006, p.86). Also, gender-based habitus was activated in cases where teachers: a) defined the rules for acceptable RTP forms in their schools, b) showed tolerance towards some RTP forms involving strength, when girls practised these and c) depending on their opinion about RTP forms that best suit the students according to their gender, possibly affected boys' and girls' participation in certain RTP forms.

- Sample teachers divide RTP forms into two categories: Games that are exclusively more appropriate for boys, since it seems that are related to masculine characteristics (fighting wrestling, punching and hitting, open hand slapping, pile on) and games that fit both genders (chasing, protect - rescue games, spinning, poke and grappling, rolling around, tickling).

- Kindergarten teachers, trying to keep their school rules, prevent students' verbal and physical confrontation, thus they prohibit competitive and physical contact games, in order to avoid any injury possibility. They, consequently, tolerate RTP forms such as chasing, spinning, tickling and protect - rescue games, if pre-schoolers play in a calm way. The rest 
of RTP cases (fighting/wrestling, punching and hitting, open hand slapping, pile on, poke and grappling) are considered to break the school rules. Thus, teachers intervene and stop RTP strength forms, when they realize that students practise them in their schools.

The issue of RTP is interesting and researchers have not been involved in Greece. It would be useful to carry out this research in more Greek kindergarten schools, especially during this current period of financial crisis when mood and behavior of the Greek population have been affected. It would also be interesting to carry out the research in the beginning of the school year, with the participation of both men and women kindergarten teachers, when the functioning culture of the school classroom is not yet consolidated, thus it cannot prevent some certain RTP forms in the kindergarten school. Finally, it would be useful to approach the kindergarten teachers' and parents' opinion on the relation between RTP and violence, as well as RTP impact on the children's self-formation, i.e. the formation of their personality.

\section{References}

Asimaki, A., \& Koustourakis, G. (2014). Habitus: An Attempt at a Thorough Analysis of a Controversial Concept in Pierre Bourdieu's Theory of Practice. Social Sciences, 3(4), 121-131. http://dx.doi.org/10.11648/j.ss.20140304.13

Boulton, M. J. (1996). A comparison of 8-and 11-year-old girls' and boys' participation in specific types of rough-and-tumble play and aggressive fighting: Implications for functional hypotheses. Aggressive behavior, 271-287. http://dx.doi.org/10.1002/(SICI)1098-2337(1996)22:4<271::AID-AB3>3.0.CO;2-O

Bourdieu, P. (1999). Language and symbolic power. Athens: Kardamitsas.

Bourdieu, P. (2000). Practical discourses for the theory of action. Athens: Plethron.

Bourdieu, P. (2002). Masculine Domination. Stanford: Stanford University Press.

Bourdieu, P. (2003). Distinction. A social critique of the judgment of taste. Athens: Patakis.

Bourdieu, P. (2006). The sense of practice. Athens: Alexandreia.

Brett, A., Valle-Riestra, D.M., Fischer, M., Rothlein, L., \& Hughes, M. T. (2002). Play in Preschool Classrooms: Perceptions of Teachers and Children. Journal of Early Childhood Teacher Education, 23, 71-79. http://dx.doi.org/10.1080/1090102020230112

Carlson, F. (2011). Big Body Play: Why Boisterous, Vigorous and Very Physical Play is Essential to Children's Development and Learning. Washington, DC: National Association for the Education of Young Children.

Cohen, L., Manion, L., \& Morrison, K. (2007). Research methods in education (6th ed.). London and N.Y.: Routledge.

Coplan, R. J., Bullock, A., Archbell, K. A., \& Bosacki, S. (2015). Preschool teachers' attitudes, beliefs, and emotional reactions to young children's peer group behaviors. Early Childhood Research Quarterly, 30, 117-127. http://dx.doi.org/10.1016/j.ecresq.2014.09.005 
Cooney, M. H., \& Bittner, M. T. (2001). Men in early childhood education: Their emergent issues. Early Childhood Education Journal, 29, 77-82. http://dx.doi.org/10.1023/A:1012564610349

DiCarlo, C. F., Baumgartner, J., Ota, C., \& Jenkins, C. (2015). Preschool teachers' perceptions of rough and tumble play vs. aggression in preschool-aged boys. Early Child Development and Care, 185(5), 779-790. http://dx.doi.org/10.1080/03004430.2014.957692

Flanders, J. L., Leo, V., Paquette, D., Pihl, R. O., \& Séguin, J. R. (2009). Rough-and-tumble play and the regulation of aggression: an observational study of father-child play dyads. Aggressive behavior, 35(4), 285-295. http://dx.doi.org/10.1002/ab.20309

Fletcher, R., May, C., St George, J., Morgan, P. J., \& Lubans, D. R. (2011). Fathers' perceptions of rough-and-tumble play: Implications for early childhood services. Australasian Journal of Early Childhood, 36(4), 131-138.

Freeman, N., \& Brown, M. (2004). Reconceptualizing Rough and Tumble Play: Ban the Banning. Advances in Early Education And Day Care, 13, 219-234. http://dx.doi.org/10.1016/s0270-4021(04)13008-5

Frost, J. L., Wortham, S. C., \& Reifel, R. S. (2008). Play and child development. Upper Saddle River, NJ: Pearson/Merrill Prentice Hall.

Giddens, A., Duneier, M., Appelbaum, R. P., \& Carr, D. (2000). Introduction to sociology. New York: WW Norton.

Handel, G., Cahil, E. \& Elkin, F. (2007). The sociology of children and childhood socialization. Los Angeles: Roxbury Publishing Company.

Hughes, M. D., Kroehler, C. J., \& Vander Zanden, J. W. (2005). Sociology: the core. New York: McGraw-Hill.

Jarvis, P. A. (2004). The role of rough and tumble play in children's social and gender role development in the early years of primary school. Unpublished Doctoral dissertation. Leeds: Leeds Metropolitan University.

Jarvis, P. (2006). "Rough and Tumble" Play: Lessons in Life. Evolutionary Psychology, 4, 330-346.

Longue, M., \& Harvey, H. (2009). Preschool Teachers' Views of Active Play. Journal of $\begin{array}{llll}\text { Research in Childhood } \quad \text { Education, } & \text { 24(1), }\end{array}$ http://dx.doi.org/10.1080/02568540903439375

Mason, J. (2002). Qualitative researching. London: Sage.

McBride-Chang, C., \& Nagy Jacklin, C. (1993). Early play arousal, sex-typed play, and activity level as precursors to later rough-and-tumble play. Early Education and Development, 4(2), 99-108. http://dx.doi.org/10.1207/s15566935eed0402_2

Mead, G. H. (1982). The Individual and the Social Self (Edited with an Introduction by D.L. 
Miller). Chicago: The University of Chicago Press.

Mihalakopoulos, G. (1990). Sociology of Education. Thessaloniki: Kyriakides.

Pellegrini, A. D. (1989). Elementary School Children's Rough-and-Tumble Play. Early Childhood

Research

Quarterly,

$4(2)$,

245-260.

http://dx.doi.org/10.1016/S0885-2006(89)80006-7

Pellegrini, A. D., \& Smith, P. (1998). Physical Activity Play: The Nature and Function of a Neglected Aspect of Play. Child Development, 69(3), 577-598. http://dx.doi.org/10.1111/j.1467-8624.1998.tb06226.x

Reed, T., Brown, M., \& Roth, S. (2000). Friendship Formation and Boys' Rough and Tumble Play: Implications for teacher education programs. Journal of Early Childhood Teacher Education, 21(3), 331-336. http://dx.doi.org/10.1080/0163638000210304

Reed, T., \& Brown, M. (2000). The Expression of Care in Rough and Tumble Play of Boys. Journal of Research in Childhood Education, 15(1), 104-116. http://dx.doi.org/10.1080/02568540009594779

Robson, C. (2007). Real world research. A resource for social scientists and practitioner researchers. Athens: Gutenberg.

Schåfer, M., \& Smith, P. (1996). Teachers' Perceptions of Play Fighting and Real Fighting in Primary School. Educational Research, 38(2), 173-181. http://dx.doi.org/10.1080/0013188960380205

Scott, E., \& Panksepp, J. (2003). Rough-and-Tumble Play in Human Children. Aggressive Behavior, 29(6), 539-551. http://dx.doi.org/10.1002/ab.10062

Smith, P. (1997). Play Fighting and Real Fighting: Perspectives on their Relationship. In A. Schmitt, K. Atzwanger, K. Grammer, \& K. Schafer (Eds.), New Aspects of Ethology (pp. 47-64). New York: Plenum Press. http://dx.doi.org/10.1007/978-0-585-34289-4_3

Smith, P. K., \& Pellegrini, A. (2013). Learning through play. In R.E. Tremblay, M. Boivin \& R. DeV. Peters (Eds.), Encyclopedia on Early Childhood Development (pp. 1-6). Montreal, Quebec: Centre of Excellence for Early Childhood Development and Strategic Knowledge Cluster on Early Child Development. Retrieved March 28, 2005, from http://www.child-encyclopedia.com/documents/Smith-PellegriniANGxp2.pdf

Stevenson, M. (2014). Activative Fathering, Children's Self-Regulation, and Social Skills. Unpublished Doctoral dissertation. Tempe: Arizona State University.

Storli, R. (2013). Characteristics of indoor rough-and-tumble play (R\&T) with physical contact between players in preschool. Nordic Early Childhood Education Reasearch Journal, 6(16), 1-15. http://dx.doi.org/10.7577/nbf.342

Sumsion, J. (2000). Negotiating otherness: a male early childhood educator's gender positioning. International Journal of Early Years Education, 8, 130-140. http://dx.doi.org/10.1080/09669760050046174 


\section{Macrothink}

International Research in Education

ISSN 2327-5499

2015, Vol. 3, No. 2

Swartz, D. (1997). Culture and Power. The sociology of Pierre Bourdieu. Chicago: The University of Chicago Press.

Tannock, M. T. (2005). Young children's rough and tumble play: An exploratory study. Unpublished Doctoral Dissertation. Victoria: University of Victoria. http://dx.doi.org/10.1007/s10643-007-0196-1

Tannock, M. (2008). Rough and Tumble Play: An Investigation of the Perceptions of Educators and Young Children. Early Childhood Education Journal, 35(4), 357-361.

Thomas, L. (2002). Student retention in higher education: The role of institutional habitus. Journal of Education Policy, 17(4), 423-442. http://dx.doi.org/10.1080/02680930210140257

Wood, E., \& Attfield, J. (2005). Play, learning and the early childhood curriculum. London: Sage.

Wyness, M. G. (2012). Childhood and society: An introduction to the sociology of childhood. Basingstoke: Palgrave Macmillan.

\section{Copyright Disclaimer}

Copyright reserved by the authors.

This article is an open-access article distributed under the terms and conditions of the Creative Commons Attribution license (http://creativecommons.org/licenses/by/3.0/). 